\title{
PENGEMBANGAN TRAINER INTERNET OF THINGS SEBAGAI MEDIA PEMBELAJARAN PADA MATA KULIAH INTERNET OF THINGS
}

\author{
Nur Hasanah ${ }^{1}$, Muhammad Izzuddin Mahali $^{2}$, Bekti Wulandari ${ }^{3}$ \\ ${ }^{1}$ Dosen, Universitas Negeri Yogyakarta \\ E-mail: nurhasanah@uny.ac.id \\ ${ }^{2}$ Dosen, Universitas Negeri Yogyakarta \\ E-mail: izzudin@uny.ac.id \\ ${ }^{3}$ Dosen, Universitas Negeri Yogyakarta \\ E-mail: bektiwulandari@uny.ac.id
}

\begin{abstract}
This research aims to produce the trainer of Internet of Things for students majoring in Informatics engineering education and assess the feasibility of the Internet of Things trainer for students majoring in informatics engineering education. In the developed trainer, the Internet of Things trainer application is used for remote control using the internet. This research is an $R \& D$ research because the result of research is product oriented in the form of trainer and companion module. This study uses a development model that consists of analysis, design, implementation and evaluation, where the location of evaluation and revision are at every stage. Data collection using a questionnaire that has a range of 1 to 4. Obtaining the next questionnaire value is converted to find out the feasibility category. The result of the research shows that the value of media trainer of Internet of things generally get the value 3,33 which interpreted in the category of Very Good and obtained some input that has been improved. Feasibility values that can be interpreted very well on the Internet of Things trainer show that this trainer can be used in classroom learning.
\end{abstract}

Keywords: Internet of Things, IoT, learning media

\begin{abstract}
ABSTRAK
Penelitian ini bertujuan menghasilkan trainer Internet of Things untuk mahasiswa jurusan pendidikan teknik Informatika dan menilai kelayakan trainer Internet of Things untuk mahasiswa jurusan pendidikan teknik Informatika. Pada trainer yang dikembangkan, aplikasi trainer Internet of Things digunakan untuk kendali jarak jauh menggunakan internet. Penelitian ini merupakan penelitian R\&D karena hasil penelitian berorientasi pada produk yang berupa trainer dan modul pendamping. Penelitian ini menggunakan model pengembangan yang terdiri dari analisis, desain, implementasi dan evaluasi, dimana letak evaluasi dan revisi berada pada setiap tahapan. Pengambilan data menggunakan angket yang memiliki rentang nilai 1 s.d. 4. Perolehan nilai angket selanjutnya dikonversi untuk mengetahui kategori kelayakan. Hasil penelitian menunjukkan bahwa nilai kelayakan media trainer Internet of things secara umum memperoleh nilai 3,33 yang diintrepetasikan dalam kategori Sangat Baik dan diperoleh beberapa masukan yang telah diperbaiki. Nilai kelayakan yang dapat diintrepetasikan sangat baik pada trainer Internet of Things menunjukkan bahwa trainer ini dapat digunakan dalam pembelajaran dikelas.
\end{abstract}

Kata kunci: Internet of Things, IoT, media pembelajaran 


\section{PENDAHULUAN}

Sumber Daya Manusia (SDM) yang berkompeten sangat dibutuhkan di dunia industri. Adanya perkembangan teknologi informasi yang pesat, SDM yang menjangkau pemahaman perkembangan teknologi informasi sangat penting peranannya. Hal tersebut dikarenakan penggunaan teknologiteknologi informasi saat ini mengalami perkembangan yang cukup pesat. Perkembangan tersebut dipengaruhi dua faktor yaitu kebutuhan pemakai dan kemajuan teknologi. Universitas Negeri Yogyakarta (UNY) sebagai salah satu bentuk pendidikan vokasi yang menyiapkan terbentuknya SDM dengan keterampilan, kecakapan, pengertian, perilaku, sikap, kebiasaan kerja, dan apresiasi terhadap pekerjaan-pekerjaan yang dibutuhkan oleh masyarakat dunia usaha/industri, diawasi oleh masyarakat dan pemerintah atau dalam kontrak dengan lembaga serta berbasis produktif (Putu Sudira, 2011). Pendidikan kejuruan dan vokasi berproses dalam mempersiapkan dan membantu peserta didik dalam mengenali dirinya sesuai dengan tahapan perkembangan vokasional, mulai dari mengidentifikasi, mengeksplorasi, mempersiapkan, memilih, hingga pada tahapan dimana peserta didik tersebut benarbenar menguasai sebuah keahlian tertentu pada suatu bidang pekerjaan sesuai dengan program keahlian yang ditempuhnya.

Penguasaan keahlian peserta didik tersebut mencakup kemampuan dalam aspek kognitif, afektif, dan psikomotorik yang saling terintegrasi satu sama lain membentuk sebuah keahlian yang utuh terhadap sebuah bidang pekerjaan tertentu. Dalam mendukung hal tersebut, maka pada proses pembelajarannya, pendidikan kejuruan dan vokasi lebih diarahkan pada penumbuhan pengalaman belajar melalui rangsangan visual, kesadaran afektif, penggalian informasi kognitif, dan pengembangan keterampilan psikomotorik. Hal tersebut diperkuat oleh Putu Sudira (2011) bahwa seberapa besar dampak sebuah pendidikan/pembelajaran sangat tergantung dari seberapa banyak atau seberapa kaya peserta didik dalam mendapat pengalaman belajar. Pembelajaran yang penuh dan kaya dengan pemberian pengalaman belajar akan memberi dampak besar dan positif terhadap peserta didik. Pengamalan belajar peserta didik sangat dipengaruhi oleh penampilan guru/dosen, sarana dan prasarana belajar (learning resources equipment), suasana akademik dan lingkungan belajar, serta dukungan perangkat ICT.

Mata kuliah internet of things merupakan salah satu mata kuliah wajib tempuh mahasiswa prodi Pendidikan Teknik Informatika. Mata kuliah tersebut juga merupakan matakuliah baru untuk semester 6 dengan kurikulum 2014. Untuk mendukung tercapainya pemahaman mengenai materi tersebut dan pengalaman peserta didik dibutuhkan modul praktek. Modul praktek yang dimaksud berupa trainer yang terdiri dari perangkat hardware dan pedoman praktek berupa buku teks yang secara garis besar berisi uraian materi, langkah praktek dan penugasan. Trainer tersebut dapat digunakan oleh mahasiswa untuk membuktikan teori yang dipelajarinya.

Berdasarkan pengalaman dari dosen pengampu mata kuliah internet of things, saat ini mata kuliah Internet of Things belum mempunyai modul/trainer untuk digunakan praktik karena mata kuliah tersebut adalah mata kuliah baru. Dalam prose pembelajaran praktik saat ini masih menggunakan ESP 8266 yang dirakit sendiri oleh mahasiswa. ESP8266 tersebut baru terbatas dengan penggunaan wifi belum menggunakan GPRS. Hal tersebut tentu membuat proses pembelajaran menjadi kurang efektif, efisien, dan mengurangi pengalaman belajar peserta didik. Diperlukan waktu yang tidak sedikit dalam persiapan sebelum mereka melakukan praktikum. Maka dari itu, perlu adanya perbaikan dalam proses pembelajaran tersebut dalam kaitannya pengoptimalan dampak belajar yang dihasilkan. Salah satu bentuk perbaikan tersebut ialah dengan pengembangan media pembelajaran praktikum berupa trainer beserta pedoman praktiknya. Berdasarkan uraian diatas, peneliti ingin mengembangkan trainer internet of things beserta dokumen panduan praktik yang dapat membantu proses pembelajaran. Berdasarkan uraian diatas, tujuan pada penelitian ini adalah untuk menghasilkan trainer internet of things 
untuk mahasiswa prodi pendidikan teknik informatika dan menilai trainer internet of things untuk mahasiswa prodi pendidikan teknik informatika.

\section{Media Pembelajaran}

Kata media berasal dari bahasa latin dan merupakan bentuk jamak dari "medium" yang berarti "perantara" atau "pengantar". Sejalan dengan Smaldino dino, et.al. (2004: 9) menyatakan bahwa, "A medium (plural, media) is a means of communication and source of information." Media mempunyai makna kata metode komunikasi dan sumber informasi. Media dapat membawa informasi antara sumber dan penenerima informasi, sehingga dapat diketahui bahwa tujuan dari media adalam memfasilitasi komunikasi.

Suatu media dapat dikatakan sebagai media pembelajaran apabila media tersebut menyediakan informasi untuk keperluan pembelajaran. Sejalan dengan Brigs (Rusman, 2009: 151) yang menyatakan bahwa, media pembelajaran sebagai "the physical means of conveying instructional content" atau cara fisik untuk menyampaikan materi pembelajaran. Sedangkan Rusman (2012: 160) menyatakan bahwa media pembelajaran merupakan suatu teknologi pembawa pesan yang dapat digunakan untuk keperluan pembelajaran. Berdasarkan uraian di atas, dapat disimpulkan bahwa media pembelajaran merupakan penyampaian materi pembelajaran dari sumber belajar.

Pembelajaran merupakan kegiatan penyampaian informasi yang diciptakan untuk memfasilitasi pencapaian tujuan yang spesifik. Keberhasilan sebuah proses pembelajaran tidak terlepas dari faktor lingkungan yang tidak terbatas pada konteks tempat yang salah satunya berupa media pembelajaran. Media pembelajaran mempunyai kedudukan penting sebagai komponen lingkungan yang diaransemen agar suatu kegiatan belajar berlangsung. Menurut Kemp \& Dayton (Rusman, 2009: 154), kontribusi media terhadap proses pembelajaran adalah: (1) penyampaian pesan dapat lebih terstandar; (2) pembelajaran dapat lebih menarik; (3) pembelajaran menjadi lebih interaktif; (4) waktu pelaksanaan pembelajaran dapat diperpendek; (5) kualitas pembelajaran dapat ditingkatkan; (6) proses pembelajaran dapat berlangsung kapan pun dan di mana pun diperlukan; (7) sikap positif peserta didik terhadap materi pembelajaran serta proses pembelajaran dapat ditingkatkan; dan (8) peran guru berubah ke arah yang positif.

Rusman (2012: 162) menyebutkan rincian fungsi media pembelajaran, yaitu: (1) sebagai alat bantu yang mampu memperjelas, mempermudah, dan mempercepat penyampaian materi pembelajaran; (2) sebagai komponen dari sub sistem pembelajaran; (3) sebagai pengarah pembelajaran; (4) sebagai pembangkit motivasi dan perhatian; (5) meningkatkan hasil pembelajaran; (6) mengurangi terjadinya verbalisme; dan (7) mengatasi keterbatasan ruang, waktu, tenaga, dan daya indra.

Berdasarkan pernyataan-pernyataan di atas, dapat disimpulkan bahwa media pembelajaran mempunyai kedudukan penting sebagai salah satu komponen pembelajaran yang berfungsi untuk menyampaikan materi pembelajaran dari sumber belajar ke pembelajar sehingga materi pembelajaran menjadi lebih jelas dan lebih mudah dipahami.

Trainer merupakan suatu set peralatan laboraturium yang digunakan sebagai media pendidikan yang merupakan gabungan antara model kerja dan mock-up. Trainer ditujukan untuk menunjang proses pembelajaran peserta didik dalam menerapkan pengetahuan/konsep yang diperolehnya pada benda nyata. Menurut Anderson (1994: 181), obyek yang sesungguhnya atau benda model yang mirip sekali dengan benda nyatanya, akan memberikan rangsangan yang amat penting bagi siswa dalam mempelajari tugas yang menyangkut keterampilan psikomotorik. Penggunaan media obyek dalam proses belajar secara kognitif untuk mengajarkan pengenalan 
kembali dan/atau pembedaan akan rangsangan yang relevan; secara afektif dapat mengembangkan sikap positif terhadap pekerjaan sejak awal latihan; sedangkan secara psikomotorik, memberikan latihan atau untuk menguji penampilan dalam menangani alat, perlengkapan dan materi pekerjaan.

Selain media objek (trainer) tersebut, terdapat media cetak yang disebut dengan modul. Media cetak merupakan pengajaran terprogram yang berbentuk buku. Modul Media Pembelajaran yang dimaksud pada penelitian ini merupakan media pembelajaran berisi prosedur pengoperasian trainer serta memuat materi, tugas, tes dan cara mengevaluasi yang dirancang secara sistematis dan menarik untuk mencapai kompetensi yang diharapkan sesuai dengan tingkat kompleksitasnya dan termasuk kedalam jenis media cetak berwujud buku. Modul yang dikembangkan diharapkan mampu meningkatkan motivasi dan efektifitas penggunaannya. Modul tersebut di antaranya memiliki karakteristik: (1) self contained, yaitu seluruh materi pembelajaran dari satu kompetensi atau subkompetensi yang dipelajari terdapat di satu modul yang utuh; dan (2) user friendly, yaitu setiap instruksi dan paparan informasi yang tampil bersifat membantu dan bersahabat dengan pemakainya, termasuk kemudahan pemakai dalam merespon, mengakses sesuai keinginan, serta penggunaan bahasa sederhana dan mudah dimengerti.

Menurut Arsyad (2010: 87 - 90) modul pembelajaran memiliki beberapa hal yang perlu diperhatikan pada saat merancang, misalnya konsistensi dalam penggunaan format dari halaman ke halaman mengenai jenis dan ukuran huruf serta jarak spasi, teks yang disusun sedemikian rupa sehingga informasi mudah diperoleh dan memiliki daya tarik agar memotivasi siswa untuk terus membaca modul pembelajaran. Tujuan utama modul pembelajaran adalah untuk meningkatkan efisiensi dan efektivitas pembelajaran baik waktu, dana, fasilitas, maupun tenaga guna mencapai tujuan secara optimal.

\section{METODE}

\section{Model Pengembangan}

Penelitian ini masuk dalam prosedur R\&D karena hasil penelitian berorientasi pada produk. Apabila produk tersebut telah mendapat validasi serta pengakuan dari ahli melalui uji alfa, baru kemudian uji beta dan dievaluasi pada implementasi sesungguhnya. Pengembangan media pembelajaran ini merujuk pada model yang ditawarkan oleh Lee \& Owens (2004). Model Lee \& Owens diadopsi untuk menekanakan fase implementasi model dengan memasukkan white box testing, dan black box testing.

Jika membandingkan model pengembangan model Lee \& Owens terhadap waktu yang dibutuhkan untuk pembuatan media pembelejaran, dapat diestimasi total proporsi waktu dalam penelitian. Karena disadari bahwa untuk menghasilkan hardware yang baik diperlukan prosedur yang benar dengan alokasi waktu proporsional. Pengembangan modul internet of things merupakan jawaban ide kreatif yang muncul dari sudut pandang setelah beberapa kali melakukan prasurvei di Program Studi Pendidikan Teknik Informatika dan telaah pustaka.

\section{Prosedur Pengembangan}

Penelitian ini masuk dalam prosedur R\&D karena hasil penelitian berorientasi pada produk. Apabila produk tersebut telah mendapat validasi serta pengakuan dari ahli melalui uji alfa, baru kemudian uji beta dan dievaluasi pada implementasi sesungguhnya. Pengembangan media pembelajaran ini merujuk pada model yang ditawarkan oleh Lee \& Owens (2004). Pelaksanaan R\&D terdiri dari dua prosedur yang digunakan yaitu penelitian dan pengembangan. Prosedur penelitian menggunakan fase asesmen/analisis, fase desain, fase implementasi dan fase evaluasi. Fase analisis pada penelitian ini 
dilakukan di kelas pada Program Studi Pendidikan Teknik Informatika FT UNY dalam bentuk prasurvei terhadap perkembangan media pembelajaran sistem kendali. Prasurvei dilakukan untuk memastikan, memperkuat dan mendukung asumsi terhadap masalah yang ada.

Pada fase analisis ini terdiri dari need assesment dan Front End Analysis. Need assessment akan dilakukan sebagai proses untuk menentukan hasil, mengindentifikasi kesenjangan antara kondisi saat ini dengan kondisi yang diinginkan (Lee \& Roadman, 1991). Untuk melakukan need assessment dengan baik dilakukan pengembangan instrumen need assessment and analysis. Prosedur need assessment dilakukan melalui survei ke lapangan dengan tujuan mengungkap hal-hal berikut: (1) Melihat kembali kondisi media pemebelajaran saat ini, lalu mengidentifikasi pengetahuan dan skill untuk pemecahan masalah di lapangan; (2) Menetapkan sistem yang ideal; (3) Membuat daftar tujuan penting; dan (4). Mengidentifikasi perbedaan melalui mencari perbedaan kondisi ideal dan kondisi aktual. Front-end Analysis yang dilakukan dalam penelitian ini bertujuan menjembatani antara kesenjangan yang ada dengan kenyataan/harapan untuk menyelesaikan masalah tersebut. Ada sembilan analisis yang dapat dilakukan yaitu: (1) analisis peserta; (2) analisis teknologi; (3) analisis situasi; (4) analisis tugas; (5) analisis kejadian penting; (6) analisis tujuan; (7) analsis media; (8) analisis data yang masih ada; dan (9) analisis biaya.

Fase desain merupakan perencanaan dari isi proyek. Desain sangat memungkinkan sebuah proyek dapat berjalan dengan baik. Rancangan desain produk disajikan dalam pra pelaksanaan pembelajaran. Kinerja media pembelajaran baru akan dapat diukur dari kemudahan implementasinya. Fase desain dalam pengembangan media pemmbelajaran meliputi :
1. Menyusun jadwal. Jadwal pengerjaan proyek dipilih untuk mempermudah penyelesaian proyek dengan mempertimbangkan unsur waktu, ketersediaan, kapasitas, SDM dan sarana. Jadwal pengerjaan proyek adalah aspek penting dan perlu diperhatikan bahwa jadwal yang telah dibuat untuk dikomunikasikan dengan tim terkait frame waktu, tujuan hingga pembagian tugas.

2. Project Team. Kesadaran akan keterbatasan sesorang dalam bidang keilmuan menyebabkan individu tidak mungkin dapat melakukan segala sesuatu secara optimal. Hal ini diadopsi dalam pengembangan proyek, termasuk dalam pendidikan dan pelatihan. Keterbatasan ini sekaligus membuka peluang untuk berkolaborasi membentuk tim proyek, untuk berkontribusi optimal sesuai bidang masing-masing. Tim proyek yang baik hendaknya terdiri dari minimal bidangbidang yang akan dikerjakan.

3. Spesifikasi Media. Mengacu desain pengembangan hardware yang baik, penelitian ini memenerapkan prinsip kesederhanaan, tata letak, keutamaan fungsi, interaksi, feedback, topografi, grafik, warna dan pendukung.

4. Content Structure (Pemetaan Informasi). Agar sebuah media pembelajaran dapat bekerja sesuai yang diinginkan perlu adanya peta informasi. Oleh karena itu, materi yang dimasukkan oleh pengembang media ke dalam media pembelajaran harus dapat menyatakan materi-materi sesuai rancangan mata kuliah Internet of Things.

Fase implementasi merupakan bagian langsung yang berkaiatan dengan hal teknis. Artinya produk akan dikerjakan tergantung bentuk pengembangan apa yang akan diacu. Langkah teknis yang paling sesuai dengan pembuatan media pembelajaran mengacu pada fase desain selanjutnya dibagi dalam tiga alur 
produksi (a) preproduction; (b) production; dan (c) postproduction and quality review. Dalam preproduction diperlukan untuk menggambarkan kejadian tersendiri dari suatu diagram aliran proses, dimana satu proses merepresentasikan seluruh media pembelajaran yang dikembangkan. Menyusun diagram alur pembuatan media dan menunjukkan sistem secara keseluruhan. Pada bagian production ini media pembelajaran akan dibuat berdasarkan rancangan preproduction. Subfase ini adalah tahapan produksi sesuai dengan desain. Menginterpretasi diagram, fungsi, tata letak, materi dan termasuk pembuatan buku pedoman pembelajaran. Termasuk proses assembling untuk masing-masing fase menjadi satu kesatuan media pembelajaran yang siap digunakan. Setelah media selesai diproduksi, maka untuk memastikan kualitas trainer tersebut dilakukan debug melalui verifikasi, yaitu uji white-box dan uji black-box. Kegiatan tersebut untuk memastikan media pembelajaran dapat bekerja sesuai fase desain hingga subfase production (fase pengembangan) sekaligus untuk meminimalisir error. Fase implementasi adalah realisasi dari fase desain dan fase pengembangan. Sehingga pada fase implementasi diharapkan media pembelajaran dapat sepenuhnya selesai. Pada fase ini pula dilakukan proses uji alfa dan uji beta, jika hasil kedua uji tersebut masuk pada kategori "baik" (skor 3,4<X $\leq 4,2$ ) maka implementasi dapat dilanjutkan ke fase evaluasi.

Fase evaluasi dilakukan untuk menjawab inti permasalahan, yaitu pengembangan media pembelajaran. Sehingga dalam permasalahan ini perlu diketahui tingkat akurasi, fungsi, konten materi dan petunjuk penggunan modul dalam pelaksanaan perkuliahan. Fase evaluasi dilakukan melalui penyelenggaraan pembelajaran di kelas Program Studi Pendidikan Teknik Informatika. Evaluasi sendiri merupakan tindakan mengumpulkan, memproses dan menganalisis informasi secara sistematik untuk memperoleh nilai nyata dari pemecahan masalah. Tanpa evaluasi tidak sulit diketahui apakah masalah telah terpecahkan dengan baik, dengan kata lain apakah situasi yang diinginkan telah sesuai rumusan masalah.

\section{Sumber Data/ Subyek Penelitian}

Subyek penelitian ini adalah mahasiswa Prodi Pendidikan Teknik Informatika yag mengikuti matakuliah Internet of Things. Mahasiswa dilibatkan dalam observasi, uji alfa (uji coba terbatas dan uji coba luas), dan validasi akhir (beta). Sedangkan dosen pengampu dan beberapa ahli media dan materi dilibatkan dalam observasi dan validasi materi \& media. Jenis data yang dihasilkan dalam penelitian ini ada dua jenis : (a) data kualitatif diperoleh dari hasil research and information collecting, uji alfa (uji coba terbatas dan uji coba luas), dan uji beta; dan (b) data kuantitatif diperoleh dari hasil evaluasi.

\section{Metode Analisis Data}

Metode analisis data yang dipakai dalam rangka menjawab rumusan masalah pada, kemudian dirinci dalam pertanyaan penelitian adalah teknis analisis deskriptif kuantitatif dan evaluatif. Tahap pertama, penelitian menguji kelayakan media pembelajaran IoT yang digunakan dalam mata kuliah Internet of Things di Prodi Teknik Elektronika. Teknis analisis deskriptif dilakukan untuk menentukan kelayakan media dalam fungsinya. Tahap kedua, fokus penelitian pada evaluasi media pembelajaran Internet of Things untuk proses menentukan metode pelatihan pada pengguna. Teknis analisis deskriptif kuantitatif dilakukan untuk mengetahui gambaran tingkat keefektifan media pembelajaran tersebut. Dalam kuisioner diberikan lima alternatif pilihan untuk memberikan tanggapan tentang media yang dikembangkan, yaitu; sangat baik dengan skor 4, baik dengan skor 4, kurang baik dengan skor 2, dan sangat kurang baik dengan skor 1 . Skor yang diperoleh kemudian dikonversikan menjadi nilai, pada skala 4, dengan acuan tabel 1 sebagai berikut : 
Tabel 1. Konversi Skor

\begin{tabular}{|l|l|}
\hline Interval Skor & Kategori \\
\hline$M+1,5$ SD s.d. $M+3$ SD & Sangat Baik \\
\hline $\begin{array}{l}M+0,0 \text { SD } \text { s.d. } M+1,5 \\
\text { SD }\end{array}$ & Baik \\
\hline$M-1,5$ SD s.d. $M+0$ SD & Kurang Baik \\
\hline$M-3$ SD s.d. $M-1,5$ SD & $\begin{array}{l}\text { Sangat Kurang } \\
\text { Baik }\end{array}$ \\
\hline
\end{tabular}

dengan keterangan;

$M \quad=$ mean ideal, dihitung dengan menggunakan rumus :

$M=1 / 2$ \{skor maksimal ideal + skor minimal ideal\} ...(2)

$S D$ = simpangan baku ideal, ditentukan dengan rumus :

Tabel 2. Konversi Data Kualitatif Menjadi Data Kuantitatif (Skala 4)

\begin{tabular}{|l|l|l|l|}
\hline \multirow{2}{*}{ Skala } & \multirow{2}{*}{ Kriteria } & \multicolumn{2}{|c|}{ Skor } \\
\cline { 3 - 4 } & & Perhitungan & Hasil \\
\hline 4 & Sangat Baik & $2,5+(1,5 \times 0,5)$ s.d. $2,5+(3 \times 0,5)$ & 3,25 s.d. 4 \\
\hline 3 & Baik & $2,5+(0 \times 0,5)$ s.d. $2,5+(1,5 \times 0,5)$ & 2,5 s.d. 3,25 \\
\hline 2 & Kurang & $2,5-(1,5 \times 0,5)$ s.d. $2,5+(0 \times 0,5)$ & 1,75 s.d. 2,5 \\
\hline 1 & Sangat Kurang & $2,5-(3 \times 0,5)$ s.d. $2,5-(1,5 \times 0,5)$ & 1 s.d. 1,75 \\
\hline
\end{tabular}

Untuk mencari skor rata-rata dalam memberikan penilaian terhadap produk yang telah dikembangkan, maka digunakan rumus;

$\mathrm{X}_{\mathrm{i}}=\frac{\sum \mathrm{x}}{\sum \mathrm{ax} \sum \mathrm{n}}$

keterangan :

$$
\begin{array}{ll}
\mathrm{Xi} & =\text { skor rata-rata } \\
\sum \mathrm{x} & =\text { jumlah skor } \\
\sum \mathrm{a} & =\text { jumlah aspek yang diamati } \\
\mathrm{n} & =\text { jumlah responden }
\end{array}
$$

\section{HASIL DAN PEMBAHASAN}

\section{Deskripsi data Need Assesment and Analysis (NAA)}

Hasil pengembangan ini berupa trainer Internet of Things yang mampu membantu dosen dalam pembelajaran mata kuliah Internet of Things. Sebelum dilakukan pengembangan media dilakukan analisis terlebiuh dahulu. Ada dua tahapan dalam melakukan analisis, yaitu melakukan need assessment dan front end analysis. Dalam tahapan ini, peneliti mendapatkan beberapa temuan diantaranya:
$S D=1 / 6$ \{skor maksimal ideal - skor minimal ideal\} ...(3)

Dari skala 4 tersebut di atas diketahui bahwa skor maksimal ideal adalah 4 dan skor minimal ideal adalah 1, sehingga diperoleh perhitungan $M i$ dan $S B i$ sebagai berikut :

$M=1 / 2(4+1)=2,5$

$S D=1 / 6(4-1)=0,5$

Berdasarkan ketentuan tersebut, diperoleh hasil perhitungan skala 4 sebagaimana dapat dilihat pada tabel 2 berikut:

1. Media pembelajaran untuk praktikum Internet of Things belum ada krena mata kuliah ini adalah mata kuliah baru di kurikulum 2014. Dari hasil tersebut maka dapat dikatakan bahwa pengembangan media pembelajaran dalam bentuk trainer sekaligus pedoman praktek menjadi hal yang sangat penting diupayakan tenaga pengajar.

2. Temuan yang didapatkan dari mahasiswa yang telah mendapatkan mata kuliah Internet of Things adalah perlunya diberikan gambaran praktik nyata sehingga akan memberikan target pencapaian hasil praktikum yang dilakukan pada saat pembelajaran praktik.

3. Media pembelajaran yang ideal untuk dikembangkan dalam mata kuliah Internet of Things berdasarkan temuan yang telah diperoleh terdiri dari beberapa kriteria. Kriteria-kriteria tersebut diantaranya: (1) perlunya pengembangan trainer sekaligus pedoman praktek yang memperhatikan perkembangan teknologi; (2) media yang 
dikembangkan perlu memberikan gambaran hasil praktik yang diharapkan.

4. Kondisi ideal dalam pengembangan media adalah memasukkan semua teknologi yang sedang berkembang.

\section{Desain}

Fase desain dalam pengembangan media pembelajaran meliputi menyusun jadwal, penentuan project team, spesifikasi media, dan pemetaan informasi. Pada spesifikasi media, penelitian ini menerapkan prinsip kesederhanaan, tata letak, keutamaan fungsi, interaksi, feedback, grafik, warna dan pendukung. Agar sebuah media pembelajaran dapat bekerja sesuai yang diinginkan perlu adanya peta informasi.

\section{Implementasi}

$\begin{array}{rrr}\text { Tahapan } & \text { implementasi terdiri dari } \\ \text { preproduction, } & \text { production, } & \text { dan } \\ \text { postproduction } & \text { quality review. } & \text { Tahapan }\end{array}$ pembuatan media Internet of Things secara berurutan adalah pembuatan skema rangkaian, simulasi kerja skema, desain boks dan layout area trainer, layout PCB dan pembuatan PCB, pemasangan komponen, pembuatan algoritma dan program, uji kinerja rangkaian, pemasangan boks, pembuatan pedoman praktik, unjuk kerja keseluruhan, valiadasi ahli media dan materi, uji pengguna terbatas, dan uji lapangan. Tahapan production diupayakan dalam pengembangan trainer sekaligus pedoman praktik menyesuaikan trainer yang dikembangkan. Termasuk proses packaging untuk masing-masing fase menjadi satu kesatuan media pembelajaran yang siap digunakan. Sebagai tambahan dan penjelas dibuat pula manual book penggunaan trainer. Secara umum pembuatan media terdiri dari membuat trainer, membuat pedoman praktik (dan manual book), unjuk kerja perangkat dan pengujian-pengujian sebagai implementasi tahapan Postproduction and Quality Review.

\section{Evaluasi}

Tahapan evaluasi ini dilakukan dua uji yaitu uji alfa dan uji beta. Uji alfa dengan mengujikan media pada para expert judgement yaitu para ahli yang ahli materi dan ahli media. Uji kelayakan materi dilakukan oleh dua ahli materi. Validasi ahli materi dilakukan oleh Bekti Wulandari, M.Pd. dan Muhammad Munir, M.Pd. Keduanya adalah staff pengajar di Program Studi Pendidikan Teknik Elektronika yang dilakukan pada tanggal 2 Oktober 2017. Sama dengan pengujian materi, pada pengujian media juga diujikan pada dua ahli media. Validasi ahli media dilakukan oleh Ponco Wali Pranoto, M.Pd dan Satriyo Agung Dewanto, M.Pd., Setelah dilakukan pengujian kelayakan baik dari ahli materi dan media tersebut, maka dilakukan revisi sesuai penilaian dan masukan para ahli. Setelah dikonsultasikan kembali dan dinyatakan sesuai maka dapat dilakukan uji beta. Uji Beta dilakukan dengan dua tahapan yaitu uji pengguna terbatas dan uji lapangan. Uji pengguna terbatas dilakukan oleh 2 mahasiswa Program Studi Pendidikan Teknik Informtika dimana mahasiswa tersebut sudah pernah mendapat mata kuliah tersebut. Selanjutnya uji lapangan dilakukan kepada 11 mahasiswa. Dari tahap uji alfa dan uji beta, media selalu mengalami revisi dengan harapan dapat memenuhi kebutuhan media dan mengoptimalkan kebermanfaatan media.

\section{Kelayakan Media Pembelajaran}

\section{Deskripsi Data Uji Alfa}

Uji alfa media pembelajaran ini dilakukan dengan pengaturan input dan melihat hasil outputnya melalui percobaan. Uji alfa mengacu paada Alessi dan Pressman. Pengujian ini fokus pada kinerja sistemsecara komprehensif, yang dilakukan berulang-ulang. Hasil uji tersaji dalam tabel 3. 
Tabel 3. Data Hasil Test Case Media Pembelajaran

\begin{tabular}{|c|c|c|c|c|}
\hline Test Case & $\begin{array}{l}\text { Skenario } \\
\text { Pengujian }\end{array}$ & $\begin{array}{l}\text { Hasil yang } \\
\text { Diharapkan }\end{array}$ & Hasil Pengujian & Simpulan \\
\hline Power & $\begin{array}{l}\text { Tombol power } \\
\text { ditekan }\end{array}$ & $\begin{array}{l}\text { Modul power mampu } \\
\text { memberikn tegangan } \\
3,3 \mathrm{~V} \text { dan } 5 \mathrm{~V}\end{array}$ & $\begin{array}{l}\text { Modul power } \\
\text { memberikan } \\
\text { tegangan } 3,3 \mathrm{~V} \text { dan } \\
5 \mathrm{~V}\end{array}$ & Valid \\
\hline $\begin{array}{l}\text { Modul } \\
\text { Push } \\
\text { button }\end{array}$ & $\begin{array}{l}\text { Push button } \\
\text { dijadikan Input data } \\
\text { program }\end{array}$ & $\begin{array}{l}\text { Modul dapat menjadi } \\
\text { data input program }\end{array}$ & $\begin{array}{l}\text { Modul pushbutton } \\
\text { mampu menjadi input } \\
\text { data program ESP } \\
\text { maupun NodeMCU }\end{array}$ & Valid \\
\hline $\begin{array}{l}\text { Module } \\
\text { lampu } \\
\text { LED }\end{array}$ & $\begin{array}{l}\text { Lampu LED } \\
\text { dinyalakan } \\
\text { menggunakan } \\
\text { program }\end{array}$ & $\begin{array}{l}\text { Lampu LED dapat } \\
\text { menyala sesuai dengan } \\
\text { program }\end{array}$ & $\begin{array}{l}\text { Lampu LED dapat } \\
\text { dinyalakan sesuai } \\
\text { dengan pengaturan } \\
\text { prigram }\end{array}$ & Valid \\
\hline ESP8266 & $\begin{array}{l}\text { Komuniksi dengan } \\
\text { Firebase dan } \\
\text { thinkspeak }\end{array}$ & $\begin{array}{l}\text { Modul ESP8266 dapat } \\
\text { menulis data dan } \\
\text { membaca data firebase }\end{array}$ & $\begin{array}{l}\text { Data firebase dapat } \\
\text { ditulis dan dibaca }\end{array}$ & Valid \\
\hline NodeMCU & $\begin{array}{l}\text { Komunikasi dengan } \\
\text { Firebase dan } \\
\text { thinkspeak }\end{array}$ & $\begin{array}{l}\text { Modul NodeMCU dapat } \\
\text { menulis data dan } \\
\text { membaca data firebase }\end{array}$ & $\begin{array}{l}\text { Data firebase dapat } \\
\text { ditulis dan dibaca }\end{array}$ & Valid \\
\hline $\begin{array}{l}\text { Potensio } \\
\text { dan } \\
\text { Arduino }\end{array}$ & $\begin{array}{l}\text { Pembacaan data } \\
\text { Potensio }\end{array}$ & $\begin{array}{l}\text { Potensio dapat } \\
\text { digunakan sebagai input } \\
\text { data variabel }\end{array}$ & $\begin{array}{l}\text { Data variable } \\
\text { didapatkan dati } \\
\text { potensio }\end{array}$ & Valid \\
\hline $\begin{array}{l}\text { Module } \\
\text { Relay dan } \\
\text { Arduino }\end{array}$ & $\begin{array}{l}\text { Aktivasi modul } \\
\text { relay }\end{array}$ & $\begin{array}{l}\text { Relay dapat } \\
\text { dikendalikan } \\
\text { menggunakan Arduino }\end{array}$ & $\begin{array}{l}\text { Arduino mampu } \\
\text { mengendalikan Relay }\end{array}$ & Valid \\
\hline $\begin{array}{l}\text { Sensor } \\
\text { DHT dan } \\
\text { Arduino }\end{array}$ & Input sensor DHT & $\begin{array}{l}\text { Sensor DHT } \\
\text { digunakana sebagai } \\
\text { input sensor }\end{array}$ & $\begin{array}{l}\text { Arduino mampu } \\
\text { membaca sensor } \\
\text { DHT sebagai data } \\
\text { input }\end{array}$ & Valid \\
\hline $\begin{array}{l}\text { Uji coba } \\
\text { tampilan } \\
\text { LCD }\end{array}$ & $\begin{array}{l}\text { Menampilkan data } \\
\text { dari Firebase ke } \\
\text { LCD }\end{array}$ & $\begin{array}{l}\text { Muncul nilai pada LCD } \\
\text { yang sesuai }\end{array}$ & LCD dapat & Valid \\
\hline
\end{tabular}

Dari tabel diatas diperoleh kesimpulan bahwa media pembelajaran yang dikembangkan secara umum menunjukkan unjuk kerja yang baik sehingga dapat dilakukan tahapan validasi selanjutnya. Setelah dinyatakan bahwa unjuk kerja valid maka dilanjutkan validasi ahli materi dan ahli media yang masing-masing dilakukan oleh dua orang dosen ahli. Aspek content dalam uji alfa ini menilai aspek materi yang didalamnya ada 5 indikator. Uji alfa spek ini fokus pada kesesuaian, kelengkapan, meningkatkan pemahaman, memberikan kesempatan belajar, dan kesesuaian dengan daya pikir. Dari data dapat diketahui bahwa dari 15 butir pernyataan terdapat 8 butir pernyataan yang diinterpretasikan sangat baik karena bernilai diatas 3,25. Sedangkan yang bernilai diatas 2,75 dan dibawah 3,25 terdapat 7 butir pernyataan yang masuk dalam kategori baik. Meskipun demikian secara umum dari sisi materi dengan skor rerata sebesar 3,4 maka dapat diintrepetasikan Sangat Baik (diatas 3,25). Dengan intrepetasi Sangat Baik tersebut maka perangkat dapat dilakukan pengujian tahap selanjutnya.

Hasil uji alfa berikutnya adalah valiadasi ahli media yang di dalamnya terdapat dua aspek penilaian yaitu teknis dan estetika. Hal yang diuji pada aspek teknis adalah kualitas alat, fleksibel, keamanan dan kemanfaatan. Sedangkan indikator pada aspek setetika adalah bentuk yang estetis, keserasian, keterbacaan, dan kerapian. Total pernyataan 
pada valiadasi ahli media ini adalah 18 butir pernyataan, dimana 10 butir pernyataan untuk aspek teknis dan 8 butir pernyataan untuk aspek estetika. Secara umum dari sisi media dengan skor rerata sebesar 3,75 maka dapat diintrepetasikan Sangat Baik (diatas 3,25). Dengan intrepetasi Sangat Baik tersebut maka perangkat dapat dilakukan pengujian tahap selanjutnya.

\section{Deskripsi Data Uji Beta}

Dilakukan uji beta dengan 2 mahasiswa baru kemudian dilakukan uji lapangan kepada 11 mahasiswa. Data hasil uji beta diperoleh melalui angket yang diberikan, responden uji beta setelah mencoba media dan jobsheet praktikum Internet of Things.

Dari data yang diperoleh, dari 18 butir pernyataan terdapat 10 pernyataan yang dapat diintrepetasikan sangat baik dikarenakan bernilai diatas 3,25 , dan 8 pernyataan yang diintrepetasikan baik dikarenakan bernilai diatas 2,75 dan dibawah 3. Meskipun demikian secara umum dari sisi materi dengan skor rerata sebesar 3,33 maka dapat diintrepetasikan Sangat Baik (range antara 3,25 s.d. 4). Dengan intrepetasi Baik tersebut maka perangkat dapat dilakukan pengujian tahap selanjutnya. Setelah dilakukan uji coba terbatas dengan 2 pengguna selanjutnya dilakukan uji lapangan.

Dari data yang diperoleh dapat diketahui bahwa dari 18 butir pernyataan terdapat 9 butir pernyataan yang diinterpretasikan sangat baik karena bernilai diatas 3,25 . Sedangkan yang bernilai diatas 2,75 dan dibawah 3,25 terdapat 9 butir pernyataan yang masuk dalam kategori baik. Dari uji lapangan ini terlihat mahasiwa merasa terbantu saat belajar dengan menggunakan media pembelajaran ini. Rerata hasil uji lapangan untuk indikator tersebut adalah 3,82. Sedangkan pernyataan "Adanya buku panduan menjadikan media pembelajaran ini aman saat Anda gunakan dalam pembelajaran" dan "Ilustrasi (Grafik, gambar, tabel) jelas" memperoleh rerata paling rendah yaitu 3,00. Hal ini dikarenakan dalam panduan penggunaan praktikum masih belum lengkap dalam penjelasan pengoperasian alat. Meskipun demikian secara umum dari sisi materi dengan skor rerata sebesar 3,31 maka dapat diintrepetasikan Sangat Baik (diatas 3,25). Dengan intrepetasi Sangat Baik tersebut maka perangkat dapat dilakukan untuk pengujian keefektifan.

Saat ini mata kuliah Internet of Things belum mempunyai modul/trainer untuk digunakan praktik karena mata kuliah tersebut adalah mata kuliah baru. Dalam prose pembelajaran praktik saat ini masih menggunakan ESP 8266 yang dirakit sendiri oleh mahasiswa. ESP8266 tersebut baru terbatas dengan penggunaan wifi belum menggunakan GPRS. Hal tersebut tentu membuat proses pembelajaran menjadi kurang efektif, efisien, dan mengurangi pengalaman belajar peserta didik. Diperlukan waktu yang tidak sedikit dalam persiapan sebelum mereka melakukan praktikum. Salah satu langkah yang diambil dengan pengembangan media pembelajaran praktikum berupa trainer beserta pedoman praktiknya.Untuk mempermudah dalam penggunaan trainer ini maka didampingi dengan sebuah modul panduan yang menjeleskan tentang penggunaan trainer dan jobsheet yang dapat menjelaskan langkahlangkah dalam melakukan praktikum menggunakan trainer tersebut.

Perangkat hardware praktek pada mata kuliah Internet of Things yang diekmbangkan adalah (1) Family ESP8266 digunakan sebagai pemrosesan utama sistem (2) Menggunakan koneksi internet baik melalui Jaringan Wifi Access Point maupun menggunakan jaringan kartu GSM/CDMA (3) Menggunakan Backend as a Service (BaaS) Firebase dan Thinkspeak sebagai basis managemen cluod database (4) Memiliki beberapa input sensor dan device (LCD, LED). Berdasarkan hasil pengujian test casedi peroleh beberapa pengujian dengan hasil yang sesuai dengan diharapkan. Hal ini menandakan bahwa trainer tersebut dapat digunakan. 
Untuk mendapatkan data tingkat kelayakan media pembelajaran dilakukan dengan cara uji kelayakan dari dosen ahli media, dosen ahli materi yang disebut dengan uji alfa. Selanjutnya dilakukan uji beta yaitu uji dari sisi pengguna yaitu mahasiswa. Uji alfa bertujuan mengidentifikasi dan menghilangkan sebanyak mungkin masalah sebelum akhirnya sampai ke pengguna. Berdasarkan hasil penelitian perolehan persentase aspek kualitas media sebesar 3,75 dan aspek kualitas materi sebesar 3,4. Dengan demikian tingkat kelayakan trainer Internet of Things sebagai media pembelajaran dikatagorikan sangat baik. Uji beta dilakukan dengan uji terbatas dan uji lapangan. Berdasarkan hasil penelitian perolehan persentase uji terbatas adalah 3,19. Dan uji lapangan adalah 3,24 dengan demikian tingkat kelayakan trainer Internet of Things sebagai media pembelajaran dikatagorikan sangat baik.

\section{SIMPULAN}

Berdasarkan hasil penelitan dan pembahasan yang telah dikemukakan pada bab sebelumnya, maka diperoleh kesimpulan sebagai berikut: (1) Pengembangan Media pembelajaran untuk mata kuliah Internet Of Things melalui tahapan-tehapan yang terdiri dari Analisis, Desain, Implementasi dan Evaluasi, dimana letak evaluasi dan revisi terletak pada tiap tahapan. Pada tahapan implementasi dilakukan pembuatan media berdasarkan desain. Evaluasi dilakukan oleh ahli materi, ahli media dan pengguna. Media yang dikembangkan mempunyai karakterikstik: (1) Family ESP8266 digunakan sebagai pemrosesan utama sistem (2) Menggunakan koneksi internet baik melalui Jaringan Wifi Access Point maupun menggunakan jaringan kartu GSM/CDMA (3) Menggunakan Backend as a Service (BaaS) Firebase dan Thinkspeak sebagai basis managemen cloud database (4) Memiliki beberapa input sensor dan device (LCD, LED); (2) Nilai kelayakan media pembelajaran ini secara umum memperoleh nilai 3,45 yang diintrepetasikan dalam kategori Sangat Baik dan diperoleh beberapa masukan yang telah diperbaiki. Dengan rincian perolehan nilai dari: (1) ahli materi sebesar 3,4 (Sangat Baik); (2) ahli media sebesar 3,75 (Sangat Baik); (3) uji 2 pengguna sebesar 3,33 (Sangat Baik); dan (4) uji lapangan kepada 11 pengguna sebesar 3,31 (Sangat Baik). Nilai kelayakan yang dapat diintrepetasikan sangat baik pada media pembelajaran menunjukkan bahwa media ini dapat digunakan dalam pembelajaran dikelas.

\section{DAFTAR RUJUKAN}

[1] Putu Sudira. (2011). Kurikulum dan Pembelajaran Pendidikan dan Pelatihan Vokasi Menyongsong Skill Masa Depan. Makalah Pengembangan Kurikulum. Bali : Politeknik Negeri Bali.

[2] Smaldino, E.S., Russel, J.D., Heinich, R., et al. (2004). Instructional Media and Technologies for Learning $\left(8^{\text {th }}\right.$ Edition $)$. New Jersey: Pearson Merril Prentice Hall..

[3] Rusman. (2012). Belajar dan Pembelajaran Berbasis Komputer: Mengembangkan Profesionalisme Guru Abad 21.Bandung: Penerbit Alfabeta.

[4] Rusman. (2009). Manajemen Kurikulum (Seri Manajemen Sekolah Bermutu). Jakarta: PT Raja Grafindo Persada.

[5] Anderson, R. H. (1994). Pemilihan dan Pengembangan Media untuk Pembelajaran. Jakarta: PT Raja Grafindo Perkasa..

[6] Azhar Arsyad. (2010). Media Pembelajaran. Jakarta : Raja Grafindo Persada. 